\title{
Banker Professional Ethics Violation in Banking Business
}

\author{
Ida Nurhayati and Eri Ester Khairas
}

\begin{abstract}
This study aims to explain what is meant by ethics in carrying out the profession as a banker, can be one of the reasons for the profession. For that, we need to understand. Qualitative research methods with normative juridical and sociological research. Analysis using a mixture of Monster Grid and Quinney. The problem of this research, Ethical issues are not made in the banker's professional guidelines. This can occur, among others, because of: 1 . Weak internal controls; 2. Supervision is avoided by non-formal factors, such as lifestyle, social and cultural factors; 3 . Not yet adhered to the ethical principles of the professional code of ethics, only because of the principles of the Banker's Code of Ethics. Specifically, it is still given to each bank to improve the code of ethics by the conditions of the bank. In the end, it can be concluded as official, SOP on each part and level, but if it is not based on ethics in every operational activity, then resolving and discussing the issue of "trust" will always occur.
\end{abstract}

Index Terms-Professional code of ethics, business, professional crime.

\section{INTRODUCTION}

Banking has one part of the financial business in society. The main characteristic of running a banking business is based on trust. The community gives trust in their work, with their expertise in managing community finances, in this case, referred to as customers. This trust often a moment that can be misused by all involved in operational activities, from the level of employees to management, with various modus operandi that can harm the community or its customers. Misuse of trust is a banking crime.

The violations committed by managers and corporations have a lot to do with ethical violations. In this case, Clinard [1] divides into two factors, namely internal factors and external factors. In internal factors, it can be concluded that various corporate management is under pressure from top management and middle managers and is a significant factor in the conduct of ethical violations and illegal behavior by corporations. [2] Business ethics that are disrupted are the existence of injustice and dishonesty towards the public, consumers, competitors, and the government. The boundary between ethical violations and illegal actions is often unclear [1].

Banks, as one form of a corporation, then the occurrence of crime, can not only be seen from one side of the corporation, but the one that runs/operates the corporation. If in banking, banking players are called bankers, and they are people who operate banking. If in its operations some irregularities or violations can harm the community (the customer) or its

Manuscript received February 20, 2020; revised May 9, 2020.

Ida Nurhayati and Eri Ester Khairas are with State Polytechnic of Jakarta, Indonesia (e-mail: ida.nurhayati@akuntansi.pnj.ac.id, eri.esterkhairas@pnj.ac.id). corporation, then it is referred to as occupational crime carried out by a professional bank or what is called a banker.

The business ethics model consists of three main components (i.e. expectations, perceptions and evaluations) that are interconnected by five sub-components (community expectations, organizational values, norms and beliefs, results of community evaluation, and reconnection). Business ethics becomes a continuous and repetitive process. There is no actual end to the process, but constant reconnection for the initiation of sequential process reactions from the business ethics model [3].

From the description above, the problem discussed here is that in addition to the existence of laws that are coercive, decisive, and formal, ethics are still needed as a complement to values and norms that can be used as guidelines in carrying out their profession. [4] Bearing in mind, not always something formal legal can regulate the rules, especially those related to the profession. Therefore, this is where the importance of ethics, which is more flexible and quickly follows the development of society [5].

This article is limited to the area of ethics in business, especially ethics for bankers. The author feels called to participate in seeing and analyzing ethical deviations by bankers. Bankers have made ethics in maintaining their professionalism. However, there are many different conditions, where the existence of ethics is ignored as a guideline that can direct work activities. Business ethics, which is the main highlight of this writing, is business ethics in the banking business.

\section{LiterAture REVIEW/ PREVIOUS RESEARCH REVIEW}

The recent empirical study of "ethical adjustment" has fused and supported the statement that for the best interests of the organization and continuing to seek ethical harmony between labor and the ethical climate they intentionally built in an integrated manner between company ethics and individuals to form an ethical culture in the company.

Göran [3] states that business ethics becomes a continuous and repetitive process. There is no actual end to the process, but constant reconnection for the initiation of subsequent process interactions from the business ethics model. Cohen [6] argues that personality traits appear to be a significant factor in the risk of fraud. What is expected by Cohen and his friends is that ethics are always carried out and continuously audited or evaluated also adjusting the professional development and society, so that ethics are always up to date and flexible.

In banking violations and even banking crimes, what happens is a violation of ethics that has been known by the perpetrators as a view, a guideline in daily behavior. This is where ethics only reaches the point of being known, but in obeying it or running, it can be something that blocks or 
makes them disobey. It needs to be traced, which is then analyzed as a finding so that it can be known. In this case, Göran [3] states that business ethics becomes a continuous and repetitive process. There is no actual end to the process, but constant reconnection for the initiation of subsequent process interactions from the business ethics model.

\section{A. Principles of Business Ethics}

Business ethics [3], [7] can be seen as an attempt to formulate and apply basic ethical principles in the field of economic relations between humans. It can also be said that business ethics highlights moral aspects in relationships between various parties involved in business activities. [8], [9] Elements that still get an essential place are critical and rational.

In the context of the business as a noble profession, business ethics invites us to try to realize a good (ethical) business and management image. In other words, business ethics merely encourages us to present business activities as a noble-ethical activity, namely the activities of people who are ethical and deserve to be entered by all those who still believe in the ethical dimension of this life. At the same time, business ethics dispel the ugly image that business is the activity of cunning dirty people, and so on.

As a field of activity in a society involving almost all members of the community, whether as entrepreneurs, managers, workers, and consumers, good business will have an enormous contribution to the lives of the community in general. The good or bad of our society and culture is more or less determined by the good or bad business behavior in our society so that business contributes to our society. [10], [11] Within this framework, business ethics has a significant contribution in building our society and culture, now and in the future.

As personal ethics or applied ethics, the principles in business ethics are the application of ethical principles in general, which can generally be stated as follows:

1) Principle of Autonomy; The attitude and ability of humans to act based on their awareness of what they consider useful to do. Autonomous people are people who are fully aware of what is their duty in the business world. He knows about the field of activity, the situation he faces, what is expected, the demands and rules that apply to the field of activity and also knows about the decisions and actions he deserves. However, on the other hand, he is still required to be responsible for his decisions and actions:

a) He is responsible to himself, or in ethical language to his conscience.

b) $\mathrm{He}$ is responsible to people who entrust all of their business and management activities to him honestly.

c) $\mathrm{He}$ is responsible to the parties involved with him in business matters.

d) $\mathrm{He}$ is also willing to account for his decisions and actions to third parties, namely the entire community that is indirectly affected by the decisions and actions of his business.

2) Honesty Principle; In the business world, honesty finds its form in various aspects:

a) Honesty is realized in fulfilling the terms of the agreement and contract.

b) Honesty also finds its form in offering excellent quality goods and services.

c) Honesty also involves working relationships within the company.

3) The Principle of Not Doing Evil and the Principle of Doing Good; Both of these principles have a moral principle that is good for others. In dealing with other people, in whatever field, we are required to be kind to them. Based on this principle, all other moral principles can be built, such as honesty, responsibility, justice and so on. That is, without the essential attitude of treating others well, we will tend to be dishonest or cheat on them, not to be responsible, not to be fair and so on.

4) Principle of Justice; This principle requires that we treat others according to their rights. The rights of others must be violated and do not need to be violated, constantly as we must be approved.

5) The Principle of Respect for Yourself; That we all have moral obligations that are of weight to respect ourselves [12].

\section{B. Principles of Banking Ethics}

A bank is a financial institution whose main business is providing credit services in the payment and circulation traffic. Financial institutions are all entities whose activities attract money from the community and distribute them to the public. So the main task of banks as financial institutions is active credit operations, namely the creation or provision of credit carried out by banks, and passively accepting deposits in the form of demand deposits, deposits, savings or other forms of deposit entrusted by the public (Indonesian Bankers, 1994).

The existence of several main bank tasks as above, then the trust factor of other parties and customers is the main thing for the smooth operation of the bank. This is also a banking ethic in relation to other parties. For this reason, bankers have a role in terms of having good, moral and banking / financial expertise.

Ethics and obligations related to duties in the banking environment for each banker, both employees and leaders as follows:

1) Banks are required to provide reports to Bank Indonesia to find out the banking and monetary positions and economic activities and the government can determine economic and monetary policies.

2) Each bank must announce the actual balance sheet and income statement every year by publishing it in the newspaper so that the public can find out.

3) Banks must maintain the financial confidentiality of customers from anyone unless there are official requirements from the Minister of Finance in writing for taxation and judicial purposes.

4) The bank officer has an obligation not to discuss the customer's finances outside the interests of the service and is obliged to maintain and maintain records or letters between the bank and its customers.

5) In terms of payment of taxes, bankers must carry out income tax deductions on salaries, wages or honorariums of their employees and are obliged to pay corporate taxes.

6. Banks must strive always to be able to fulfil the promises or agreements that have been agreed with their customers.

7) Banks must also provide objective, impartial and 
non-binding advice to their customers.

One of the things that must be avoided between bankers and customers is to avoid personal relationships that can lead to unhealthy relationship, for example, bankers provide convenience for a customer due to tribute or gift and the like because this will harm other customers who behave naturally in their working relationships with banks (Hidayat, 2012.)

\section{Discussion RESULTS}

The essence of a bank is how to transform an "intangible" commodity in the form of trust, which is the true value of a bank. How do banks attract and use money from the public and managing money from the community will form their own image or image in the minds of the public It is this trustworthy commodity that gives rise to the bank a sense of responsibility both morally and financially. This can be illustrated in the following picture:

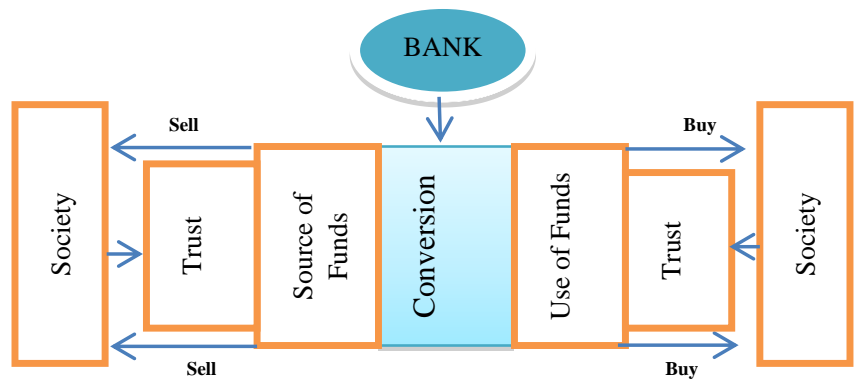

Fig. 1. Bank as intermediation institutions.

In Fig. 1, it shows that through the people's trust, fund flows into the bank as a source of funds. From the source of these funds, managed by the bank in accordance with the agreement/binding between customers and banks. The management, the results delivered by the bank to the public in the form of the funds needed by the community. Fund distribution to the public of the funds managed by the bank is also on primary bank confidence to the user community funds. Therefore, banks as intermediaries between the community depositing funds and the people who need funds, then there is a relationship as mentioned above. These relationships are all based on trust by the two parties, namely the community to the bank and the bank to the community.

There are 8 principles of banking ethics, namely:

1) Principle of obedience

In this principle, everyone everywhere has rules that they must obey, as well as bankers who are required to comply with banking regulations, laws, government policies, labor regulations concerning the community, customers, government, owners and employees.

2) Principle of Secrecy

Bankers are required to maintain confidentiality, especially with customers and the confidentiality of their positions.

3) Recording Truth Principles

Every bank officer must maintain records or documents and record all transactions correctly and maintain confidentiality

4) Competing Health Principles

This competition can be internal, that is, between parts within the bank itself and external, namely competition between banks. In terms of more to provide services and promotions for any services provided by the bank, each bank must maintain a healthy competitive climate.

5) Principle of Honesty Authority

Trust and authority that have been given by the parties concerned in this case the government, customers, owners, communities and employees should remain united and not be misused for non-ethical interests that have been agreed upon.

6) Principle of Limitations of Information

Even though bank officers and bankers were asked to be informative about outsiders, their nature was limited.

7) Professional Honor Principles

Every bank officer or banker is required to obey the honor of the profession by avoiding things such as collusion, giving gifts, tribute, and facilities from other parties who want convenience in terms of bank procedures.

8) Principles of Social Responsibility.

This responsibility is more directed at the government, customers, owners or the community in terms of carrying out banking operations [12].

\section{RESEARCH METHODS}

This study uses a qualitative approach, starting with studying secondary data, in the form of decision files from the Supreme Court. This is done so that it can be known with certainty about the cases of banking crimes that occur, such as who, their position, the type of crime, and where the convicted banking criminals are serving their sentences.

Secondary data is obtained through the study of documents in the form of case files of violations and banking crimes in several banks in Indonesia. Case files were obtained from the District Court and the Supreme Court.

Clinard-Quinney [1] and conducted by Graaf and Huberts [13] that both of his studies on crime related to work, position, and profession.

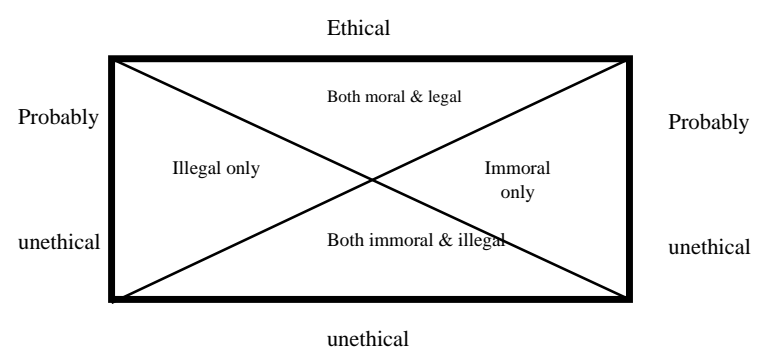

Source: Neuman [14]

Fig. 2. Tipology of legal and moral actions in research.

In Fig. 2, it shows that for ethical behavior it is done on the choice between moral behavior and legitimate behaviour whereas unethical behaviour is found in the choice of immoral and unethical behaviour. For the possibility of unethical behaviour, only illegzal behaviour and only immoral behaviour. It is clear that for ethical behaviour, it includes moral behaviour and does not violate formal provisions.

The theorical dimensions of Clinard-Quinney [1] are integrated into the "Monster Grid" model Graaf-Huberts [13] namely (Table I): 
TABLE I: DIMENSIONS OF CRIMINAL BEHAVIOUR OF CLINARD-QUINNEY

Dimensions of

Criminal

Behavior

\begin{tabular}{|c|c|}
\hline $\begin{array}{l}\text { Legal and ethical } \\
\text { aspects are } \\
\text { violated }\end{array}$ & $\begin{array}{l}\text { The definition of crime is human behavior } \\
\text { created by authorized agents in a politically } \\
\text { organized society. Laws governing crime are } \\
\text { formulated by segments of society that have the } \\
\text { power to accommodate their wishes in public } \\
\text { policy so that criminal law regulates behavior } \\
\text { that is considered threatening the ruling class. }\end{array}$ \\
\hline $\begin{array}{l}\text { The criminal } \\
\text { career of the } \\
\text { perpetrator }\end{array}$ & $\begin{array}{l}\text { The behavior of the offender is shaped by the } \\
\text { extent to which established norms and activities } \\
\text { are part of the development of individual crime. } \\
\text { The development of the social role of the } \\
\text { perpetrator, including the role he plays, about } \\
\text { self-concept, developments in criminal activities, } \\
\text { and identification with a crime }\end{array}$ \\
\hline $\begin{array}{l}\text { Group support for } \\
\text { crime behavior }\end{array}$ & $\begin{array}{l}\text { The behavior of actors is supported by the norms } \\
\text { of the groups from which they come. Some are } \\
\text { defined as crimes according to normative } \\
\text { patterns studied in particular social and cultural } \\
\text { environments. Criminal behavior group support } \\
\text { varies according to the association of actors with } \\
\text { differences in norms that have been integrated } \\
\text { into social groups. }\end{array}$ \\
\hline $\begin{array}{l}\text { The relationship } \\
\text { between bad } \\
\text { behavior and } \\
\text { legitimate } \\
\text { behavior }\end{array}$ & $\begin{array}{l}\text { In this context, people develop and carry out } \\
\text { actions that are relatively likely to be defined as } \\
\text { crime. }\end{array}$ \\
\hline $\begin{array}{l}\text { Social reactions } \\
\text { and legal } \\
\text { processes }\end{array}$ & $\begin{array}{l}\text { Crime behavior is generally defined to vary in } \\
\text { the various types and number of reactions they } \\
\text { receive from the community. Social reactions } \\
\text { range from the level of agreement or } \\
\text { disagreement to sanction procedure policies. The } \\
\text { treatment is given, and its implementation for } \\
\text { each type of crime is different from formal } \\
\text { punishment. }\end{array}$ \\
\hline
\end{tabular}

Included in these five dimensions are a variety of phenomena related to crime, namely, the formulation and administration of criminal law, the development of people and behaviors that can be defined as criminal, and reaction to social behavior, Five (5) dimensions based on certain typological assumptions of criminal behavior system theory.

From the two studies that the author referred to as the method in this study, then in this study which focused on several types of banking crimes committed by bankers with management level, then there are three types of crimes that the author will discuss in this study.

The three types of cases in this study are:

1) Credit Case; this is done because most of the cases that occur in banking are related to credit problems. In tracing, both in documents (documents) obtained from formal institutions such as the District Court, Supreme Court, and electronic media, the fictitious credit cases are the most frequent.

2) The practice of banks in banks; this is so-called because the perpetrators in carrying out the crime acted on behalf of the bank where he worked. The existence of multiple records carried out by the perpetrator. In the recording, it is as if it were an official record or administration within the bank, but actually, it is not right/invalid. Because the offender does not formally become the customer of the bank, but the money is in his power, and not into the bank's assets.

3) Cases of false records.

\section{RESUlts}

Offenders in jobs and professions usually regard themselves as honorable citizens, not as criminals. Because the offender is in a legitimate job, it is difficult to imagine that every activity in work that can be a fact of the crime. [13], [15] This nonprime conception of self is one of the critical elements in the form of evil. Those who violate financial beliefs, such as embezzlers, could engage in such behaviour only when they can describe their behaviour in a way that allows them to adjust their opinions about themselves as trusted people with their concept of themselves as users of funds that entrusted or property. These offenders define their situation with rationalizations that allow them to regard them as essentially non-criminal violations. They think their behaviour is only a "loan", justified by unusual conditions or unshareable problems that can be solved by their position in violation of trust [1], [16].

Generally, professional crime is not from a legal definition, but the behaviour of professional criminals is criminals from respectable circles. [17] That is the way crime is committed, which is determined by the character's behaviour of professionals. [18], [19] Professional crime perpetrators, each of whom is categorized as law such as fraud/fraud, then the reality is associated with statutory regulations. Professional crime, for the most part, is sociological construction [1].

TABLE II: RESULTS OF RESEARCH ON VIOLATIONS OF ETHICS AND BANKING CRIMES

\begin{tabular}{llllll}
\hline \hline Dimension & $\begin{array}{l}\text { Case 1 } \\
(\mathrm{Am})\end{array}$ & $\begin{array}{l}\text { Case 2 } \\
(\mathrm{Nn})\end{array}$ & $\begin{array}{l}\text { Case 3 } \\
(\mathrm{Tn})\end{array}$ & $\begin{array}{l}\text { Case 4 } \\
(\mathrm{Md})\end{array}$ & $\begin{array}{l}\text { Case 5 } \\
(\mathrm{Dv})\end{array}$ \\
\hline $\begin{array}{l}\text { 1. Legal and } \\
\text { Ethical Aspects } \\
\text { Violated }\end{array}$ & $\mathrm{V}$ & $\mathrm{V}$ & $\mathrm{V}$ & $\mathrm{V}$ & $\mathrm{V}$ \\
\hline $\begin{array}{l}\text { 2. Career Crime } \\
\text { Actor }\end{array}$ & $\mathrm{V}$ & $\mathrm{V}$ & $\mathrm{V}$ & $\mathrm{V}$ & $\mathrm{V}$ \\
\hline
\end{tabular}

3. Crime

Behaviour V

Group Support

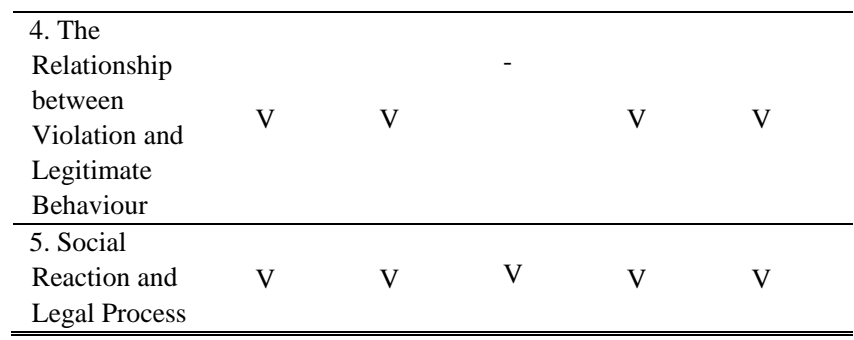

\section{Information}

Sign V: shows the fulfilment of the dimensions of ethical violations at once and crime by the perpetrator.

Sign -: shows that the perpetrator does not fulfil the violation of ethics and crime.

This situation can be indicated that the level of obedience, compliance of each banker is not the same. Several factors influence it, for example, loyalty factors that are wrong to the leader. However, most are lifestyle factors while private parties cannot hide the violations of their bankers, because of external audits from Bank Indonesia, as well as the enthusiasm to always prevent banking violations and crimes by always making regular reports to Bank Indonesia as a 
central bank and banking supervisor throughout Indonesia.

From Table II above, it can be explained in the following table, which is an elaboration between the theoretical dimensions of Clinard-Quinney [1] and findings in the field of ethical violators in banking crimes who are serving sentences in the Medaeng-Surabaya Penitentiary and Institutions Female Correctional Services Bandung. Following this explanation, a table of violators of bankers' code of ethics in banking crimes was found in the results of this study.

TABLE III: THE VIOLATIONS OF THE BANKER'S CODE OF ETHICS BY INFORMANTS

\begin{tabular}{llllll}
\hline \hline & Case & Case & Case & Case & Case \\
$\begin{array}{l}\text { P Principles of Indonesian } \\
\text { Banker's Code of Ethics }\end{array}$ & 1 & 2 & 3 & 4 & 5 \\
\hline $\begin{array}{l}\text { 1. A banker obeys and } \\
\text { adheres to the applicable } \\
\text { laws and regulations }\end{array}$ & $\mathrm{V}$ & $\mathrm{V}$ & $\mathrm{V}$ & $\mathrm{V}$ & $\mathrm{V}$ \\
\hline $\begin{array}{l}\text { 2. A banker makes a correct } \\
\text { record of all transactions } \\
\text { related to the activities of his } \\
\text { bank }\end{array}$ & $\mathrm{V}$ & $\mathrm{V}$ & $\mathrm{V}$ & $\mathrm{V}$ & $\mathrm{V}$ \\
\hline
\end{tabular}

\begin{tabular}{llllll}
\hline $\begin{array}{l}\text { 3. A banker avoids unfair } \\
\text { competition }\end{array}$ & - & - & - & - & - \\
\hline $\begin{array}{l}\text { 4. A banker does not abuse } \\
\text { his authority for personal } \\
\text { gain }\end{array}$ & V & V & V & V & V \\
\hline $\begin{array}{l}\text { 5. A banker avoids } \\
\text { involvement in decision } \\
\text { making if there is a conflict } \\
\text { of interest in decision } \\
\text { making }\end{array}$ & V & V & V & V & V \\
\hline $\begin{array}{l}\text { 6. A banker maintains the } \\
\text { confidentiality of his bank } \\
\text { customers }\end{array}$ & V & V & V & V & V
\end{tabular}

\begin{tabular}{|c|c|c|c|c|c|}
\hline $\begin{array}{l}\text { 7. A banker can take into } \\
\text { account the adverse effects } \\
\text { of each policy set by his } \\
\text { bank on the economy, social, } \\
\text { and environment }\end{array}$ & $\mathrm{V}$ & $\mathrm{V}$ & $\mathrm{V}$ & $\mathrm{V}$ & V \\
\hline $\begin{array}{l}\text { 8. A banker does not receive } \\
\text { gifts or rewards that enrich } \\
\text { themselves and their } \\
\text { families, which can enrich } \\
\text { themselves and their } \\
\text { families }\end{array}$ & $\mathrm{V}$ & $\mathrm{V}$ & $\mathrm{V}$ & V & V \\
\hline $\begin{array}{l}\text { 9. A banker does not commit } \\
\text { a disgraceful act that can } \\
\text { harm the image of his } \\
\text { profession }\end{array}$ & V & $\mathrm{V}$ & V & V & $\mathrm{V}$ \\
\hline
\end{tabular}

In Table III above, it illustrates that in all the cases taken in this study, all cases have violated all guidelines for the banker's code of ethics, from the principles of the first to the 9th.

The Banker's Code of Ethics referred to here, is only a general and general guideline for bankers. From the code of ethics, each bank is given the freedom to specify and develop it by the conditions of each bank. Therefore, the banker's code of ethics is still prevalent.

\section{CONCLUSION}

In the context of banking crimes committed by bankers, there is a violation of the banker's code of ethics. Although in this study using banking crime cases that have been decided by the court, but in this study, the emphasis is more on the violation of the ethics of bankers as an initial condition that occurs in every case of violation and banking crime. So there is a kind of adage that "every crime (especially banking) there is an ethical violation, but in every ethical violation it is not necessarily violating the law". Ethical violations cannot be ignored, because of all the informants of the perpetrators of banking violations and crimes, before being formally processed by law enforcement officials [20] they have been given the most substantial punishment of ethical violations namely being fired as bank employees or bankers. This shows that there are separate things between the process of violating ethics and the formal process of social reaction carried out by law enforcement officials. In ethical violations, bankers have been processed internally in banking according to the professional code of ethics. Following the conduct norm in each bank that has implemented in the Standard Operating Procedure in each part, task and authority contained in each bank.

\section{CONFLICT OF INTEREST}

Under these conditions, there will be a conflict of interest, on the one hand as a professional banker, by carrying out the principle of being a banker. But on the other hand, there are acts of violation of the law, which ignores the professional principles of bankers. For example, embezzlement, corruption.

\section{AUTHOR CONTRIBUTION}

This paper is mainly addressed to bankers, bank management, law enforcement officials, as well as students of banking finance studies programs

\section{ACKNOWLEDGMENT}

Our gratitude goes to the Director of the Jakarta State Polytechnic, Deputy Directors, Chairpersons of the Accounting Department, Colleagues, my daughter and all those who helped carry out this conference.

\section{REFERENCES}

[1] R. M. B. C. Quinney, Criminal Behaviour System: A Typology, 2nd ed. North Carolina: Chapel Hill, 1972.

[2] N. M. Schell-Busey, The Deterrent Effects of Ethics Codes for Corporate Crime: A Meta-Analysis, 2009.

[3] G. Svensson and G. Wood, "A model of business ethics," J. Bus. Ethics, 2008.

[4] P. Ermongkonchai, "Understanding reasons for employee unethical conduct in thai organizations: A qualitative inquiry," Contemp. Manag. Res., 2010.

[5] J. F. Wozniak, "C. Wright Mills and higher immorality: Implications for corporate crime, ethics, and peacemaking criminology," Crime, Law Soc. Chang., 2009.

[6] J. Cohen, Y. Ding, C. Lesage, and H. Stolowy, "Corporate fraud and managers' behavior: Evidence from the press,” J. Bus. Ethics, 2010.

[7] M. E. Sharpe, Business Ethics, New York: Armonk New York, 2005.

[8] J. Heath, "Business ethics and moral motivation: A criminological perspective," Journal of Business Ethics, 2008.

[9] I. R. Sonny and K. A. Haryono, Etika Bisnis. Membangun Citra Bisnis Sebagai Profesi Luhur, Jakarta: Kanisius, 1995.

[10] S. H. Appelbaum, L. Vigneault, E. Walker, and B. T. Shapiro, "(Good) corporate governance and the strategic integration of meso ethics," Soc. Responsib. J., 2009.

[11] A. Kirana, Etika Bisnis Konstruksi, Yogyakarta: Kanisius, 1996 
[12] N. Clinard and Adzani, Etika Perbankan, 2012.

[13] G. Graaf and L. W. J. C. Huberts, "Portraying the nature of corruption using an explorative case study design," Public Adm. Rev., 2008.

[14] Y. K. Djamba and W. L. Neuman, "Social research methods: qualitative and quantitative approaches," Teach. Sociol., 2002.

[15] M. Mustofa, Kleptokrasi-Persekongkolan Birokrat-Korporat Sebagai Pola White Collar Crime di Indonesia, Jakarta: Kencana Prenada Media Group, 2010.

[16] G. E. Mugalu, "The role of senior leadership in ethical behaviour of financial institutions: A case study," Capella Univ., 2010.

[17] D. Huynh, "Premption V. punishment: A comparative study of white collar crime prosecution in the United States and the United Kingdom," J. Int. Bus. Law, 2010.

[18] M. Mustofa, Kriminologi, Edisi Kedu, Bekasi: Sari Ilmu Pratama, 2010.

[19] P. Gottschalk, "Executive positions involved in white \& hyphen collar crime," J. Money Laund. Control, 2011.

[20] M. Dion, "Ethical leadership and crime prevention in the organizational setting," J. Financ. Crime, 2008.

Copyright $\odot 2020$ by the authors. This is an open access article distributed under the Creative Commons Attribution License which permits unrestricted use, distribution, and reproduction in any medium, provided the original work is properly cited (CC BY 4.0).

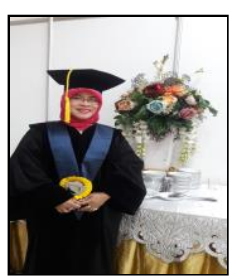

Ida Nurhayati is an associate professor and civi servant lecturer at the Jakarta State Polytechnic who was previously a University of Indonesia Polytechnic from 1994 to the present. She also teaches in several other universities, which, among others, until now at the Jakarta Police Science College in the doctoral program. She finished her undergraduate and postgraduate education in the field of law and the last doctorate in criminology from the University of
Indonesia in 2015. She is a lecturer in banking law, banking crime, an professional and business ethics courses. The research conducted focuses more on the fields of business law, banking law and professional ethics. Her published book is titled Professional Ethics and Business. Besides lecturing, her is also the head of Research and Comminity Services Center.

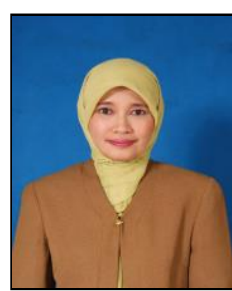

Eri Ester Khairas received a bachelor of English education from Teacher's Institute and Educational Sciences (IKIP) Jakarta in 1985. She received both her master of humanity (M.Hum) and doctoral (Dr.) degrees in linguistics from Padjadjaran University in 2009 and 2017, respectively. She has some experiences in lecturing English. She has been teaching English at State Polytechnic of Jakarta (PNJ) since 1985. From 2004 to 2007, she taught English for different faculties at University of Indonesia. Then, she was an English lecturer of Trisakti School of Management and Tarumanagara University from 2008 until 2015. Besides lecturing, she is currently running her job as the head of Language Center at State Polytechnic of Jakarta. 